\title{
2
}

\section{Australia's military after the Second World War: Legacies and challenges}

\author{
John Blaxland
}

This chapter provides a brief overview of the challenges faced by the Australian armed services as they emerged from the Second World War. It looks at how they adjusted to the changed regional dynamics after the war, the massive shrinkages in size, the new missions that emerged including the provision of occupation forces in Japan and rehabilitation at home, and the fluid security dynamics as the postwar order settled into the confrontation of the Cold War. The legacies of war for the armed services and the veterans themselves are also considered. The chapter illustrates that while the United States had played an enormous role in helping to defend Australia during the Second World War, the Australian armed forces retained their distinctive British-derived practices, procedures, equipment and orientation. This legacy would endure for decades.

The Second World War left an indelible impression on Australia's military. The three armed services, the Royal Australian Navy (RAN), the Australian Military Forces (now known as the Australian Army) and the Royal Australian Air Force (RAAF), were transformed into professional, proven and well-equipped defenders of Australia and contributors to allied military operations abroad. Australians had fought across the globe alongside other British Empire forces in the European and Mediterranean theatres as well as the Pacific and Indian Oceans. 
They had also fought alongside US forces, notably in the South West Pacific Area under the command of US General Douglas MacArthur, while retaining British-derived equipment and practices.

The British influence would prove remarkably resilient in terms of policy orientation, military doctrine, procedures, equipment and uniforms. Rank insignia, for instance, remained distinctly British, albeit with some noticeable local variants, and RAAF and RAN contingents evinced few distinctive features in their uniforms, apart from the iconic slouch hat. For the RAN, practices and standards remained closely UK-aligned. The same was the case for the RAAF, even though increasingly US-sourced aircraft were in use. During the war the Army had published and promulgated training bulletins reflecting both home-grown tactical innovations and shared notes and lessons learned from other parts of the British Empire.

Along the way, the three armed services had grown almost exponentially to meet the wartime demand for specialisations inherent in self-reliant armed forces. Schools, for instance, proliferated to cover a wide range of military specialisations, including engineering and military intelligence, and a wide range of combat-related skills. A unique Australian military identity, metaphorically born in 1915, developed and matured to become more capable and more reliant on its own capabilities, albeit within the context of a grand alliance encompassing the United States and Britain's empire.

In essence, the Australian armed services at the end of the war were world-class and among the largest in the world. The RAAF briefly was the world's fourth largest air force. ${ }^{1}$ Australia's land forces ranked about 16th in the world at their peak, with a force of 464,000 troops. ${ }^{2}$ The RAN, with about 680 ships in 1945 , was still enormous, but it was dwarfed

1 At the end of the Second World War, the United States, the Soviet Union and Britain were the three major air powers in the world. At its peak in 1944, the Royal Canadian Air Force provided the fourth largest allied air force, but after Germany's defeat it began a process of rapid reduction. On Japan's surrender, the RAAF stood as the fourth largest air force in the world, but did not remain so for long. 'World's fourth largest air force?', Pathfinder 119 (September 2009), reproduced in Pathfinder collection 4 (2010): 123-26, at: airpower.airforce.gov.au/sites/default/files/2021-03/PFV04-Pathfinder-CollectionVolume-4.pdf.

2 Albert Palazzo, The Australian Army: A history of its organisation, 1901-2001 (Melbourne: Oxford University Press, 2001), 176; Tom Gargaro, 'What country had the largest army in World War II?', Quora post, at: www.quora.com/What-country-had-the-largest-army-in-World-War-II (accessed 16 September 2020). 
by the 6,768-ship US Navy. ${ }^{3}$ With the euphoria of the war's end and the demand for labour to be made available to redevelop the economy, however, they dramatically shrank back close to their prewar levels in a remarkably short time frame, mostly over the course of 1945 and 1946.

With much of the force raised specifically for wartime and with demobilisation tied to the end of the war, an interim arrangement to maintain forces was devised in early 1945. The interim arrangements were necessary to enable the initial postwar requirements to be met including the occupation of Japan, repatriation of prisoners of war and internees, maintenance of order until restoration of civil rule in occupied territories and the removal and disposal of large quantities of surplus military supplies and equipment. By February 1946, the Interim Army would come to include those members of the Australian Military Forces who were on continuous full-time duty on 1 October 1945 and personnel who joined after that date. ${ }^{4}$

\section{Postwar repatriation and peacekeeping challenges}

The task of repatriating over 150,000 soldiers back home, including 20,000 former prisoners of war in parts of Southeast Asia and Japan, presented the Australian forces and the Commonwealth Government with major logistical challenges. Shipping tonnage was at a premium and much work was required for moving people, as well as facilitating the return of the former colonial authorities and assisting with reconstruction. Japanese forces in much of the eastern end of the Netherlands East Indies, now Indonesia, surrendered to Australian forces. Administering this force of more than 300,000 military personnel while working to arrange a handover of authority to the postwar rulers proved challenging. With Indonesia's independence leaders having declared independence as Japan surrendered, there was considerable conjecture over to whom Australian forces should ultimately hand over authority.

3 'US ship force levels 1866-present', Naval History and Heritage Command, at: www.history. navy.mil/research/histories/ship-histories/us-ship-force-levels.html (accessed 18 September 2020).

4 Palazzo, The Australian Army, 197. 
The Australian Government under Ben Chifley played an advocacy role on behalf of the Indonesians. Mindful of Australia's sympathetic position towards the Indonesians, Australian advocacy was welcomed by the Indonesian independence leaders. Eager to play a constructive role, Australia volunteered to send peacekeepers. In the end, Dutch authorities resumed their place as colonial masters - at least on an interim basis and their rule was resisted by the newly declared Republic of Indonesia. Australia followed Britain's lead and complied with Dutch demands, but this was a fraught enterprise. By August 1947 Australian staff were seconded to the UN Good Offices Committee for Indonesia, including four Australian military observers - the world's first UN peacekeepers. These were Australian Army Brigadier LGH Dyke and Major DL Campbell, Commander HS Chesterman (RAN), and Squadron Leader DT Spence (RAAF). Ongoing fighting occurred through to the Dutch withdrawal from Indonesia in 1949, but by then Australian troops were well and truly out of the picture. ${ }^{5}$

Prior to that, however, many of the Japanese captives were subject to war crimes trials that endured for many months after the war. Australian lawyers, interpreters, guards and support staff played a critical role in prosecuting war criminals. Australian forces were also instrumental in facilitating the repatriation of tens of thousands of Japanese soldiers back to Japan. In fact, with competing pressures to repatriate and demobilise Australian soldiers, while handing over governance arrangements to Dutch authorities, these tasks proved increasingly challenging as the months passed after the cessation of hostilities and the number of Australians remaining in uniform dwindled.

\section{Postwar security concerns}

While only a fraction of the force would be maintained after the war, that which was retained reflected a broad range of capabilities that had been developed in the intervening years of war. This was largely because the postwar Australian armed forces that emerged by the late 1940s were not just a repeat of those that remained after demobilisation in the aftermath of the First World War. The RAAF, for instance, had not

5 'United Nations Good Offices Committee Indonesia (UNGOC) 1947-1951', Australian War Memorial, at: www.awm.gov.au/collection/CN500115 (accessed 18 September 2020). 
existed in 1918 and the range and sophistication of aircraft types and the accompanying support requirements to maintain them had grown exponentially in the intervening years. Naval platforms had evolved considerably as well, with entire new classes of vessels, equipped with previously unheard-of technologies (including radar and eavesdropping equipment), incorporated or soon to be incorporated into the fleet (notably aircraft carriers).

Land forces had gone through a similar transformation. The Australian Military Forces of the interwar years had been based on militia units with a preponderance of infantry, supported by a modicum of artillery, engineers and cavalry units. The interwar militia largely ignored logistics (along with much else). Back then, though, the expectation remained that much of the logistical and technical backup for high-end warfighting would come from Britain. Yet given the focus on continental defence, how Britain might be of much help for supplies and technical matters seems to have been questionable at best. Finances were the key constraint in the interwar period and would be so again after the war. ${ }^{6}$ By 1945 , however, the Australian Army maintained relatively sophisticated capabilities ranging across the armoured, airborne, jungle, amphibious and special operations domains. What's more, many of these capabilities were supported by home-grown logistical and administrative support arrangements and training schools as well as Australian industry. ${ }^{7}$ Admittedly, many of the weapons and equipment types remained licensed copies of British origin.

At first, Australia's postwar security concerns revolved around ensuring the former enemy states, notably Japan, were disarmed and their arsenal disabled. This was seen as fundamentally important in order to prevent them from being able to stage a repeat of their wartime actions. It soon become evident, however, that Japan and Germany were unlikely to present a significant threat in the foreseeable future. At first, there was a degree of optimism in the Chifley Government about the postwar order. Australia played a prominent role in establishing the United Nations, in part reflecting this optimism. Indeed, Australia's external affairs minister,

6 Palazzo, The Australian Army, 98.

7 See AT Ross, Armed and ready: The industrial development and defence of Australia 1900-1945

(Wahroonga: Turton \& Armstrong, 1995). 
Herbert 'Doc' Evatt, was appointed President of the United Nations in 1948 in large part as recognition of Australia's enthusiasm for the United Nations as the mechanism for managing the postwar world order.

As it happens, the Chifley Government's benign view soon stood at odds with the views developing in London, Washington and Ottawa. Erstwhile wartime ally the Soviet Union soon emerged as the principal adversary of the United States and Britain. On 5 September 1945, three days after the signifying of the surrender on USS Missouri in Tokyo Bay, a cipher clerk from the Soviet embassy in Canada, Igor Gouzenko, defected to the West with revelations of large-scale Soviet espionage in North America. Indeed, Gouzenko's defection reverberated around the world, including in Australia, where the Soviet Union had been engaged in espionage during the war - this continued apace after the cessation of hostilities. ${ }^{8}$

In addition to emerging Cold War tensions, Australia emerged from the Second World War with a different mindset towards United Kingdom authorities. While there remained a strong sense of still being British, there was a marked distinction between the British of the United Kingdom and of self-governing and now more independent dominions like Australia. No longer would Australian leaders feel compelled to fall into line with directives from London-based prime ministers. Never again, for instance, would the melancholy duty of a war declaration be an automatic invocation, as had been the case when Robert Menzies was prime minister in September 1939. The appropriation of the Statute of Westminster as an Act of the Australian Commonwealth Parliament in October 1942 put an end to that. Thereafter, the relationship would remain cordial and close, but with a much sharper focus on the distinction between the national interests of the United Kingdom in contrast to those of Australia. ${ }^{9}$

At the same time as a closeness was re-emerging in the ties between Australia and the United Kingdom, the relationship with the United States appeared to drift as US interests and focus shifted elsewhere. While Australia had been America's wartime ally, the United States was initially not interested in extending a security guarantee to Australia after the war. The Americans understood that, despite the setbacks of 1942 with the fall of Singapore, Australia remained in Britain's orbit and as Britain returned

8 This is covered in some detail in David Horner, The spy catchers: The official history of ASIO, vol. 1, 1949-1963 (Sydney: Allen \& Unwin, 2014).

9 John Blaxland, Strategic cousins: Australian and Canadian expeditionary forces and the British and American empires (Montreal: McGill-Queens University Press, 2006), 52. 
to govern its territories in the 'Far East', Australian ties with Britain would be reinforced. Notably, Australia also remained a member of the British pound sterling economic area (made up of most British Commonwealth countries, excluding Canada), whereby Australia’s currency remained fixed in value to Britain's. Britain also remained Australia's principal trading partner through the immediate postwar decade, with much of Australia's trade transiting through the Suez Canal and the Mediterranean Sea, where Britain remained influential. Australia's armed forces, therefore, maintained their wartime disposition to remain orientated towards British models, standards and equipment types, even if sometimes locally manufactured or assembled.

The ramifications of the emerging Cold War between the Soviet Union and the United States (and their respective security partners or allies) were not immediately clear at war's end. It would take some time, including a growing number of signs of Soviet-US confrontation, before American resolve to form a network of alliances crystallised in response. Australia would not sign the Australia, New Zealand and United States (ANZUS) Treaty with the United States and New Zealand until after the onset of the Korean War. Nonetheless, in the meantime, Australia remained a security partner of the United States in the occupation of Japan from 1946 to 1951, alongside other participating British Commonwealth nations.

Australia was eager to participate in the occupation of Japan as one of the victors. While eager to prevent resurgent Japanese militarism, the Australian Government demonstrated an overwhelming sense of security at the end of the Second World War. This is most evidently manifested in the pace and scale of demobilisation.

The existential fears of 1942 effectively vaporised in August 1945. It is in this context that the three services demobilised the overwhelming majority of the more than 600,000 personnel still serving in uniform at war's end. The government faced a gargantuan task, sending hundreds of thousands of their soldiers, sailors, airmen and airwomen back to their homes to return to their families, readjust, find work and get on with their lives after six years of war. Indeed, the armed services had reached nearly 1 million members at the height of the expansion by late 1942. As the tide of war turned, however, and as demands for labour in support of domestic industry and agriculture grew to meet the demands of the war itself, from as early as 1943 the government of prime minister John Curtin had set about demobilising those deemed surplus to requirements, particularly 
land forces. In response, each of the three armed services faced similar but distinct circumstances and challenges as they sought to demobilise and adjust to the postwar circumstances.

\section{Postwar plans}

A few months after the end of the war, in March 1946, the Chiefs of Staff Committee considered an 'Appreciation of the strategical position of Australia'. It saw Australia as protected by its geographic position and the collective security system of the United Nations, but beyond that, Australia was 'unable to defend herself unaided against a major power'. The only viable contender for the title was the Soviet Union. ${ }^{10}$ Australian forces, the paper argued, should be organised to fulfil the following requirements:

a. A Naval Mobile Task Unit consisting of aircraft carriers with their escorts, capable of forming part of an Empire Task Force and cooperating with the United States Navy;

b. A Fleet Train for the maintenance of a Mobile Task Unit;

c. A Sea Frontier Force consisting of escorts for shipping, and for the seaward defence of bases;

d. Amphibious craft for combined operations;

e. Standard Army formations designed for operations on normal terrain, and for amphibious operations but capable of conversion to meet the conditions of jungle warfare;

f. Army Garrison forces for the protection of bases against sea and air raids and for internal security;

g. Adequate maintenance provision for the Forces under (e) and (f);

h. An Air Mobile Task Force, including units for long range missions and transportation, ready to move wherever required for strategic purposes or in support of the other Services; and

i. Air units for the protection of bases and focal areas against sporadic raids. ${ }^{11}$

10 Stephan Frühling, A history of Australian strategic policy since 1945 (Canberra: Defence Publishing Service, 2009), 11.

11 'An appreciation of the strategical position of Australia (February 1946)', in Frühling, A history of Australian strategic policy since 1945, 61-62. 
Over 18 months later, reflecting the heightened concerns about the emerging Cold War, the updated 'Appreciation of the strategical position of Australia' in 1947 also added the requirement for a training and maintenance organisation for the support of the forces 'and for expansion in war. ${ }^{12}$ In practice, not everything on this list would be achieved in the immediate postwar years, but this guidance provided the framework that set the parameters in the early postwar years for the three armed services: the Air Force, the Army and the Navy.

\section{The Royal Australian Navy}

The RAN had grown from a strength of 5,010 personnel in 1939 to nearly 40,000 personnel at its height, operating on more than 300 vessels, consisting of dozens of warships including corvettes, frigates, destroyers and cruisers. ${ }^{13}$ The RAN did not operate aircraft carriers or submarines during the war, but aircraft carriers would come to be acquired shortly thereafter, although submarines were not included until the late 1960s. While the fleet shrank dramatically after the cessation of hostilities, many of its duties endured, including participating in the British Commonwealth Occupation Force (BCOF) in Japan and in conducting minesweeping operations in and around the South Pacific, clearing mines laid during the war from the harbours and waterways to enable commercial and naval traffic to pass unhindered. This meant that there remained considerable scope for naval personnel to serve after the war if they wished to do so.

The RAN had been well represented at the surrender signing ceremony in Tokyo Bay, with 10 Australian warships present. Two would remain on station as part of BCOF, although that force slowly shrank as its postwar occupation obligations wound up. Still, the presence with BCOF left the RAN, along with its RAAF and army counterparts, with readily available forces that would come to be deployed following the outbreak of the Korean War in mid-1950.

12 'An appreciation of the strategical position of Australia (September 1947)', in Frühling, $A$ history of Australian strategic policy since 1945, 131.

13 David Stevens, 'The RAN: A brief history', Navy.gov.au, at: www.navy.gov.au/history/featurehistories/ran-brief-history (accessed 4 January 2019). 
The postwar RAN was, in a number of respects, a more sophisticated force, having recognised the challenges of coalition warfighting, and witnessed the transformation of naval warfare generated as a result of the air war at sea and other advances in naval technology. It was with this in mind that the RAN acquired two aircraft carriers from Britain in 1947. HMAS Sydney and HMAS Melbourne were acquired in succession, with HMAS Sydney ready for tasking by the time of the Korean War in late $1950 .{ }^{14}$ For an island continent, naval forces would always play a prominent role in the nation's defence strategy. The wartime role for land forces would similarly be self-evident to many, but after the war, the fate of land forces would be subject to greater questioning.

\section{The Australian Army}

At its peak in late 1942 and early 1943, the Australian Military Forces, or what we now call the Australian Army, consisted of a force that included 14 divisions. This force included the infantry divisions of the militia, namely the 1 through 5, and 11 and 12, Australian divisions. It also included the infantry divisions of the Second Australian Imperial Force (2 AIF), namely 6, 7 and 9 Divisions, noting that 8 Division was in captivity. In addition, there were three mechanised divisions, namely 1 Armoured Division and 1 and 2 Australian Motor Divisions (later 2 and 3 Armoured Divisions). ${ }^{15}$ The 'War establishment' (that is, the personnel planning number for the Australian Army) in September 1943 was for an organisation employing 370,300 troops. ${ }^{16}$ Out of a population of just over 7 million people, the force that expanded dramatically from 1939 to 1942 shrank at an equally dramatic and accelerating pace as the war's end approached.

Despite the surprising scope and breadth of the Army's capabilities, it had emerged in a disparate manner that compounded the postwar arrangements. By 1945 there were three separate enlistment organisations grouped under the banner of the Australian Military Forces. These included the Permanent Military Force (PMF), the Citizen Military Force (CMF)

14 See Anthony Wright, Australian carrier decisions: The acquisition of HMA Ships Albatross, Sydney and Melbourne, Papers in Australian Maritime Affairs No. 4 (Canberra: Royal Australian Navy Maritime Studies Program, 1998), 57.

15 Chart: 'Distribution of the Australian Army, May 1942', National Archives of Australia (NAA) (Vic): MP729/6, 37/401/759, cited in Palazzo, The Australian Army, 170-71.

16 Palazzo, The Australian Army, 175. 
and the all-volunteer Australian Imperial Force (AIF), which had been raised specifically for expeditionary use during the war. The disbandment and repatriation of the AIF and the CMF was a priority. ${ }^{17}$

Table 2.1: Australian Military Forces divisions in 1943

\begin{tabular}{|l|l|l|}
\hline Division designation & Higher formation & Comments \\
\hline 1 Australian Division & 2 Australian Army & Militia \\
\hline 2 Australian Division & 2 Australian Army & Militia \\
\hline 3 Australian Division (Jungle) & New Guinea Force & Militia \\
\hline 4 Australian Division & Disbanded early 1943 & - \\
\hline 5 Australian Division (Jungle) & New Guinea Force & Militia \\
\hline 6 Australian Division (Jungle) & New Guinea Force & 2 AlF \\
\hline 7 Australian Division (Jungle) & New Guinea Force & 2 AlF \\
\hline 8 Australian Division & In captivity & 2 AlF \\
\hline 9 Australian Division (Jungle) & New Guinea Force & 2 AlF \\
\hline 11 Australian Division (Jungle) & New Guinea Force & Militia \\
\hline 12 Australian Division & Northern Territory Force & Militia \\
\hline 1 Australian Armoured Division & HQ Reserve & Militia \\
\hline 2 Australian Armoured Division & Disbanded early 1943 & Former 2 Australian \\
\hline 3 Australian Armoured Division & - & $\begin{array}{l}\text { Formerly 1 Australian } \\
\text { Motor Division }\end{array}$ \\
\hline 2 Australian Corps \& assorted \\
brigade formations & 1 Australian Army & $\begin{array}{l}\text { NE Reinforcement } \\
\text { Training Centre }\end{array}$ \\
\hline
\end{tabular}

Source: Drawn from Albert Palazzo, The Australian Army: A history of its organisation, 1901-2001 (Melbourne: Oxford University Press, 2001), 176-79.

The 'Army Post War Plan' of 1946 provided for the establishment over five years of two brigade groups and an armoured regiment as part of the PMF, with a strength of 11,880 personnel. This was to be the first peacetime regular operational army for Australia. In addition, two divisions and an armoured brigade would be retained as the CMF, with 43,423 personnel as well as headquarters and fixed establishments of another 20,759, making a total of 76,062, including 33,641 personnel in

17 D Maclean, 'The development of the Australian Army: A study in policy and capabilities' (BA(Hons) thesis, University of New South Wales Canberra), 3. 
the PMF. ${ }^{18}$ In the end, these numbers were aspirational and never quite realised, but most of the forces that were maintained as part of the PMF would be retained overseas as part of BCOF in Japan.

Australias land force contributions to BCOF formed the basis for the Australian Regular Army that emerged from the 1947 'Army Post War Plan'. ${ }^{19}$ Notably, this included the conversion of the 65, 66 and 67 Australian Infantry Battalions, which had been raised at the end of the war for special service with BCOF, into the 1, 2 and 3 Battalions of the Royal Australian Regiment (otherwise known as 1RAR, 2RAR and 3RAR). ${ }^{20}$ British-pattern equipment, insignia and procedures endured, with many conscious of their status as members of a force nominally identified as British as much as it was, in practice, substantively Australian.

\section{The Royal Australian Air Force}

The RAAF would face a similar pressure to demobilise. Over 200,000 Australians had served in the RAAF during the war, operating over 70 squadrons of aircraft including bomber, fighter, reconnaissance and amphibian squadrons. Australians had also made a significant contribution to Britain's defence through the Empire Air Training Scheme, having been placed in RAAF and Royal Air Force (RAF) squadrons. Many of the Australians who signed up for the Empire Air Training Scheme ended up participating in the European and Mediterranean campaigns, including the Normandy invasion and the advance into Germany. ${ }^{21}$

The 1946 plan for the postwar RAAF proposed a force of 19,483 personnel with the overwhelming majority in the permanent force. They would operate a mobile task force, including three long-range/ground attack

18 Defence Committee Minutes 460/1946, 19 November and 19 December 1946, Appendix B, cited in Wright, Australian carrier decisions, 140; Maclean, 'The development of the Australian Army', 4.

19 'Army Post War Plan', March 1947, Australian War Memorial (AWM): AWM 123, Box 95/4.

20 David Chinn, 'Raising a regular infantry force' in Duty first: A history of the Royal Australian Regiment, ed. David Horner and Jean Bou, 2nd ed. (Crows Nest: Allen \& Unwin, 2008), 1.

21 See John McCarthy, A last call of empire: Australian aircrew, Britain and the Empire Air Training Scheme (Canberra: Australian War Memorial, 1988); 'Empire Air Training Scheme', Australian War Memorial, at: www.awm.gov.au/articles/encyclopedia/raaf/eats (accessed 17 January 2019). 
fighter, three heavy bomber and two transport squadrons, and static units including four interceptor squadrons and mixed heavy bomber/ground reconnaissance squadrons. ${ }^{22}$

The jet age had yet to reach the RAAF and the fleet of aircraft the nation retained at the end of the war remained exclusively propeller-driven. They would be employed in support of BCOF in Japan, with three fighter squadrons deploying there in 1946, although this force was gradually reduced to one (77) squadron by $1948 .^{23}$

The decision was made in 1946 to acquire and then produce under licence the RAAF's first jet engine aircraft, the British De Havilland Vampire. The first three Vampires were built in the United Kingdom. Thereafter, 80 were built by the Commonwealth Aircraft Corporation (CAC) in Melbourne with the first one flying in June 1949. Additional Vampire training aircraft were also built. The Vampire-equipped RAAF 78 Wing, incorporating 75 and 76 Squadrons, would deploy to Malta in support of Britain's NATO commitments commencing in 1952. ${ }^{24}$

In the meantime, when the Soviet Union imposed a land blockade on Berlin, the RAAF contributed a dozen sets of aircrew to operate RAF Dakota transport aircraft in support of the relief efforts. ${ }^{25}$ Interoperability with the British was a given. The relatively seamless integration of the Australian aircrew into British operations reflected the enduring legacy of the wartime Empire Air Training Scheme.

Meanwhile, demands for working alongside US counterparts would increase from mid-1950. RAAF 77 Squadron, still based at Iwakuni with its propeller-driven Mustang fighter aircraft, was conveniently placed to assist US-led efforts to counter the North Korean invasion of South Korea in mid-1950. Elements of RAAF 77 Squadron were promptly deployed, flying ground attack missions and bomber escort missions in support of US forces. The squadron soon relocated to Korea, supporting ground forces from a range of airfields. With the early introduction of Soviet-sourced MiG jet aircraft in support of the North Korean forces, the

22 Defence Committee Minutes 460/1946, 19 November and 19 December 1946, Appendix C, cited in Wright, Australian carrier decisions, 141.

23 Royal Australian Air Force: A snapshot history 1921-2015 (Canberra: Air Power Development Centre, 2015), 124.

24 'A79 DHA Vampire', RAAF Museum Point Cook, at: www.airforce.gov.au/sites/default/files/ minisite/static/7522/RAAFmuseum/research/aircraft/series2/A79.htm (accessed 30 September 2020).

25 Royal Australian Air Force, 131. 
Mustangs proved obsolete. In time, the Mustang would be replaced by the Meteor - a British-sourced, twin-engine jet aircraft with considerably greater power but less manoeuvrability than the Soviet MiGs or American F86 Sabre aircraft used by the US Air Force. With Sabres in short supply and Meteors the only viable option, the RAAF subsequently had to adjust the spectrum of missions it could viably undertake. CAC-built Sabres would become the mainstay of the RAAF's fighter aircraft fleet once they became available after the Korean War. ${ }^{26}$

\section{British precedents}

As we have observed, despite having worked closely with the US armed forces since 1942, the Australian armed services still operated largely on British lines, following British-derived procedures and, principally, British-pattern military equipment. For both world wars, Britain had managed to secure the commitment of large dominion and Indian armies that could plan, fight, shoot, communicate and sustain themselves, in concert with the British Army and with each other, during the era of the two world wars. ${ }^{27}$ While Britain's power was waning, the legacy of the investment in equipment, doctrine and procedures, and the shared experiences of the British and Australian military forces, combined to generate a lasting effect. The RAN, for instance, remained closely tied to British procedures, customs, traditions, uniforms and equipment, while becoming increasingly familiar with US Navy protocols. The Australian Army, similarly, remained closely modelled on British moderated patterns of organisation. With so much invested in terms of military hardware, there was little incentive to do other than retain British-pattern weapons, procedures, communications technology and uniforms.

In the latter stages of the war, plans were afoot to re-equip Australian forces with American kit in order to contribute to the planned Allied invasion of Japan. The Canadian Army, facing similar pressures to conform to American patterns in order to remain involved, had already begun converting forces from British patterns to American patterns. Canadian

26 See Richard Hallion, 'The air war in Korea: Coalition air power in the context of limited war', in In from the cold: Reflections on Australia's Korean War, ed. John Blaxland, Michael Kelly and Liam Brewin Higgins (Canberra: ANU Press, 2020), 121-42, doi.org/10.22459/iftc.2019.06.

27 See Douglas E Delaney, The Imperial Army project: Britain and the land forces of the dominions and India, 1902-1945 (Oxford: Oxford University Press, 2018). 
forces invaded Kiska Island in the Aleutians, for instance, alongside American troops in August 1943, employing American equipment and procedures. ${ }^{28}$ But with the main invasion averted by the early surrender of Japan, the impetus for these changes in Australia dissipated.

Increasingly independent, Australia was a latecomer to the Statute of Westminster - an act of Britain's parliament in Westminster in 1931 that removed nearly all of Britain's authority to legislate for the dominions such as Canada, Australia and New Zealand. This had the effect of making them fully sovereign nations in their own right. Canada acted on it quickly, but it only came into effect in Australia following its passage through parliament in Canberra after the fall of Singapore in 1942. Despite this devolved authority, Australia remained eager to maintain and reinforce its ties with Britain. Reflecting this mindset, in mid-1943 the Curtin Government had decided that the key to Australia's postwar defence lay in participating in collective security arrangements. ${ }^{29}$

The Australian Army 'Post War Plan' of 1947 reflected the prevailing economic, strategic and military orientation of the nation towards Britain and empire. ${ }^{30}$ This pattern of conformity with Britain applied particularly to the RAN and the Australian Army, and to a lesser extent to the RAAF, its inventory having become populated with some American aircraft. Indeed, with Britain's return in 1945 to Malaya and Singapore, Australia would look to continue coordinating its defence policy with the United Kingdom.

Without a strong incentive to change models, there remained compelling reasons for Australia to maintain, for instance, the British-derived wireless signals communications standards and equipment. This enabled Australia to maintain its links with Britain's global communications network but also helped ensure interoperability of its land, naval and air forces. ${ }^{31}$ The efficiencies of scale, the economy of effort and the benefits of interoperability would endure for the better part of the following two decades.

28 Desmond Morton, A military history of Canada: From Champlain to Kosovo, 4th ed. (Toronto: McClelland \& Stewart, 1999), 189.

29 'Post War Defence Policy', Minute, 7 February 1944, NAA: A816/1, 14/301/275, cited in Palazzo, The Australian Army, 193.

30 'Army Post War Plan', March 1947, AWM: AWM 123, Box 95/4, 1-4.

31 See John Blaxland, Signals, swift and sure: A history of the Royal Australian Corps of Signals 19471972 (Melbourne: R.A. Signals Corps, 1998), 1-10. 
In the absence of any particular appetite from the United States for formal ties with Australia beyond the war, Australia's arrangements centred around engagement with Britain. As the armed forces demobilised and began planning for the postwar period, endeavours to standardise the training and organisation of the Australian forces meant the links would continue. Such links included personnel exchanges and joint weapons and equipment research and development, not to mention the similarities in workaday mutual understandings.

This was the case with contributions Australia would make as part of BCOF in Japan from 1946 to 1950. Australia played a leading role in BCOF, but the very title of the organisation pointed to the enduring significance of the connections with Britain. This high degree of interoperability between the forces of the British Empire would also help facilitate a close coordination of effort by British Commonwealth forces at the outset of the Korean War in 1950.

\section{Other legacies}

Surprisingly enough, the wartime experience of the Australian armed forces did not lead to a great sense of shared purpose, organisationally. After all, to a large extent, the RAAF had operated as part of a British-led force in the Mediterranean and Europe, and as part of a US-led force in the Pacific campaigns. Similarly, Australia's land forces were more closely aligned with their British counterparts while operating in the Mediterranean and Middle East and then with their US counterparts when fighting in the Pacific. The RAN likewise had aligned itself with its British and American counterparts to contribute to a wartime strategy formulated mostly in London and Washington. Australia's experience in leading BCOF in Japan arguably could have helped develop a level of inter-service collaboration between the three armed services, but with the operational tempo rapidly diminished and the force largely withdrawn in a short time frame, there was little prospect of that level of inter-service interaction ensuing. As a result, what came to be known in the 1980s as the Australian Defence Force remained a disparate group of separate armed forces, with their own government departments and ministers for navy, army and air. 
For the nation, the legacy of war was felt widely, far beyond the realm of the armed forces themselves. With hundreds of thousands of returned veterans, the Returned Sailors, Soldiers and Airmen Imperial League of Australia (what is now known as the Returned and Services League, or RSL) proved to be an influential body with considerable social and political clout. In the meantime, the Repatriation Department (the precursor to the modern-day Department of Veterans Affairs) oversaw the support provided for disabled military veterans, and widows of military personnel as well as their dependents. Arguably, however, considerable trauma lay unaddressed, beyond the reach of these organisations. What had been called 'shell shock' or 'combat neurosis' would reverberate for the Second World War generation as well. The extent of the damage on society is hard to measure, but is widely considered to have had a devastating knockon effect on postwar society. Joan Beaumont's Broken nation addresses this tragedy with respect of the legacy of the First World War, but the issue recurs. ${ }^{32}$

\section{Reflections}

In conclusion, Australia's military went through a dramatic transformation after the Second World War. Having expanded rapidly, the three armed services quickly returned almost to their prewar state and size. Technology and experience drove some changes, notably the establishment of a postwar regular or permanent military land force.

The lingering legacy of British-derived technology and operating concepts developed and practised during the two world wars was profound and would have a lasting effect, not least because there was little spent on replacing wartime equipment in the immediate postwar years. While the Australian armed forces had operated closely with their US counterparts in wartime, there had been little imperative during the Pacific War to bolster interoperability by adopting US-derived procedures, practice and equipment. Even when based in Australia from early 1942, General MacArthur had operated his headquarters as an American organisation, not a particularly closely integrated one. Australian forces, with their considerable operational experience predating American entry into the war, retained the British-derived approach to warfare. That approach

32 Joan Beaumont, Broken nation: Australians in the Great War (Sydney: Allen \& Unwin, 2013). 
would linger after the war - a phenomenon reinforced by the evident US disinterest in providing any immediate security guarantees to Australia once the war ended.

While only a small residual force was available to be contributed to the Korean War in 1950, what was available drew on the legacy of the Second World War, with British-derived practices, procedures and equipment, albeit with an increasingly distinctive Australian flavour. As it happens, the postwar plans for the armed services came to reflect a pattern of organisation that would change incrementally over time. This would notably include a shift towards US-sourced and NATO-standard equipment and practices. But momentum for this reform was still several years away and would have to wait until after the eclipse of Britain's imperial ambitions following the Suez Crisis of 1956. That process would commence with the 1957 defence review and some interesting experimentation with US-derived pentagonal organisational structures. ${ }^{33}$ Still, military practitioners in the early twenty-first century would recognise many of the hallmarks of their modern Australian Defence Force in the plans that were laid out in 1946 and 1947. Even through to the early twentieth century, UK ties and shared practices would permeate Australian practices, even as ties with the United States deepened. ${ }^{34}$

33 See John Blaxland, Organising an Army: The Australian experience, 1957-1965 (Canberra: Strategic and Defence Studies Centre, 1989).

34 This issue is explored in John Blaxland, The Australian Army from Whitlam to Howard (Melbourne: Cambridge University Press, 2014). 
This text is taken from Fighting Australia's Cold War: The Nexus of Strategy and Operations in a Multipolar Asia, 1945-1965, edited by Peter Dean and Tristan Moss, published 2021 by ANU Press, The Australian National University, Canberra, Australia.

doi.org/10.22459/FACW.2021.02 